[Review Paper]

\title{
Bioethanol Production from Lignocellulosic Biomass Requiring No Sulfuric Acid: Mechanochemical Pretreatment and Enzymic Saccharification
}

\author{
Shinji Fujimoto, Hiroyuki Inoue, Shinichi Yano, Tsuyoshi SaKaKi, Tomoaki Minowa*, \\ Takashi ENDO, Shigeki SaWAYAMA, and Kinya SAKANISHI \\ Biomass Technology Research Center, National Institute of Advanced Industrial Science and Technology, \\ 2-2-2 Hirosuehiro, Kure, Hiroshima 737-0197, JAPAN
}

(Received December 17, 2007)

\begin{abstract}
Bioethanol has become an important product recently. Manufacture depends on sugar or starch, but such processes conflict with the requirements for food supply. Lignocellulose has high potential as feedstock for bioethanol, and has been the focus of much research and development. Sulfuric acid is generally used for saccharification or pretreatment of lignocellulose, but we have developed a saccharification process not requiring sulfuric acid, which is more environment friendly, combining mechanochemical pretreatment and enzymatic saccharification processes. We studied the process design, and presented the technical and economical portfolio. Based on this portfolio, we developed low energy mechanochemical treatment and low cost saccharification processes. The commercialization of our system is expected to begin soon.
\end{abstract}

\section{Keywords}

Lignocellulosic biomass, Bioethanol, Mechanochemical pretreatment, Enzymatic saccharification,

Hydrothermal treatment, Process design

\section{1.はじめに ${ }^{1), 2}$}

最近, 原油価格の高騰と地球温暖化対策の要因から, 燃料工 タノールやバイオディーゼル燃料（BDF）などの液体バイオ燃 料への関心と需要が世界的に高まっている。特に, 燃料エ夕 ノールは米国とブラジルで既に大量に生産，消費されているほ か，中国，インド，タイなどでも急速に使用量が増加している。 わが国でも2003年の法改正で3\% までのエタノールをガソリ ンへ混合することが認められ, エ夕ノール生産と併せた E3（エ タノール $3 \%$ 混合ガソリン) 使用の実証事業が複数実施されて おり，また2007年にはエタノールを原料としたオクタン価向 上率であるエチルターシャリーブチルエーテル（ETBE）を添 加したガソリンの販売が首都圈で開始されている。

現在の燃料エタノールの原料は，サトウキビ等からの糖液ま たはトウモロコシ, キャッサバ等のデンプンである。これらの 利用は農作物の新たな需要の開拓にもなり, 農業政策としても 重要である。しかし，本来食用や飼料用のために栽培されてい たこれらの作物が燃料用にも使用されることで, 資源の不足と 価格騰貴の問題が起こることが従来から懸念されてきたが, 最 近それが現実のものになりつつある。特に，穀物価格は 2007 年には世界的に上昇し，日本でも多くの食品が值上げされた原 因になった。中国やインドなどの人口が多い国で食料需要が増 えていること，世界的な株安傾向で投資マネーが穀物に向かっ

\footnotetext{
* To whom correspondence should be addressed.
}

* E-mail: minowa.tom@aist.go.jp
たこと等いくつか要因があると考えられるが，燃料エ夕ノール 用の需要が増えたこともその一つであることは確かであろう。 このため中国では新規の燃料エタノール工場では穀物を原料に することを禁止するに至った。

このような問題が存在するため, 燃料エタノールの原料とし て食用と競合しない農産廃棄物や木質系などの資源を利用する ことが期待されている。これらはセルロース,ヘミセルロース, リグニンの 3 成分を主要な構成要素としているため, リグノセ ルロース系バイオマスと総称されるが, これらを原料とする燃 料は第2世代バイオエタノールと呼ばれ，食用資源を原料とす る第1世代バイオエタノールとは区別して考えられている1)。

糖やデンプンからのエタノール生産は基本的に酒造と同じで あるので, 第 1 世代バイオエタノールの製造は技術的には容易 である。しかし第2世代バイオエ夕ノールの生産は, 現時点で は多くの技術的課題を抱えており，また製造工程も複雑である。 特に, リグノセルロース系バイオマスの主成分であるセルロー スは構造が強固であり, 同じグルコースのポリマーであるデン プンと比べてもはるかに分解が難しい。そのため, セルロース をいかに効率良く（もちろん低コストで）分解するかが, 研究 開発の最大のポイントとなる。

セルロースの分解には硫酸等の酸を使用する方法と酵素によ る方法があり, 現時点では酸分解法の方がコスト面で有利であ ると考えられている。しかし酸分解法には, 糖の過分解による 収率低下と発酵阻害物質の生成, 耐酸性材料使用の必要性, 廃 酸の処理等の問題が存在し, これらは酸を使用する以上避けら れない本質的な問題であるので，今後大幅にコストを削減する 
ことは困難であると考えられている。一方，酵素法は，現状で は酵素コストが高いので不利であるが，今後の研究開発により 酵素コストが劇的に下がる可能性があり，酸を使う方法に比べ て環境調和型でもあることから, 研究開発においては世界的に 酵素糖化法が主流になっている。たた，酵素を木質等に直接加 えても，セルロースはリグニンとへミセルロースによって保護 されているので，ほとんど反応しない。そのためこの保護を外 して酵素反応を受けやすくするために何らかの前処理が不可欠 である。この前処理に酸を使用する方法もあるが，上述した酸 使用に伴う問題が発生する可能性が大きい2)。

産業技術総合研究所バイオマス研究センターでは上記の観点 から，酸を使用しないリグノセルロース系バイオマスからのエ タノール生産システムの研究開発を行っているので, その技術 内容について解説する。

\section{2. プロセスシミュレーションによる開発指針の検討 33,4$)$}

プロセスの開発を行う上で, 実験的な要素技術開発は重要で あるが，それのみではその開発がプロセス全体でどのように効 率を向上させるのか，あるいは経済性にどのように影響を及ぼ すのか全体像が見えづらい。プロセスシミュレーションは，そ のプロセスの生産性, 経済性, 環境性等について事前に評価, 検討を行うことができるため, 実験的な要素技術開発とプロセ スシミュレーションを組み合わせることで，より効率的にプロ セス開発を行うことができる。

我々の研究センターでは, BTL（Biomass To Liquid）/ETBE 液体燃料製造トータルシステムを提案している。本システム は, 粗粉砕, 水熱処理およびメカノケミカル処理による前処理, 酵素糖化，エ夕ノール発酵，ETBE 合成反応からなる ETBE 製 造プロセスと，これらの工程から排出される残さを原料とした 水蒸気ガス化, 合成ガス精製, Fischer-Tropsch（FT）合成反応, 水素化分解からなる BTL プロセスが組み合わされたシステム である。より効率的な開発を目的として，本システムに対して プロセス設計およびプロセスシミュレーションを行い，本シス テムの将来性や技術開発の指針について検討した。

\section{1. プロセスシミュレーション}

プロセスシミュレーションには市販の定常状態プロセスシ ミュレーターPRO/II（インベンシス・シムサイ(株)）と Microsoft Office Excel（マイクロソフト(株)）を用いた。

本システムの基本フローを Fig. 1のように構築した。木材は 左上から投入されて前処理，糖化，発酵，蒸留と右下に流れて エタノールとなり（成分分離・エタノール製造プロセス），工 タノールはさらに ETBE 製造プロセスで製品 ETBE となる。こ れらの工程からの残さは BTL 製造プロセスで製品 BTLとなる。 さらに，本プロセスシミュレーションでは，BTL/ETBE 液体燃 料製造システムに発電，熱利用を組み合わせ，外部からの電力 や熱供給を必要としない完全自立型システムとした。シミュ レーションに必要なデータとしては, 木材組成データ, システ 厶構成成分の熱力学デー夕, コストデー夕, 実験デー夕がある。 木材組成は，リグニン，七ルロース，へミセルロース抽よ゙灰 分を $27 \%, 50 \%, 20 \%, 3 \%$ とし, 平均分子構造モデルを $\mathrm{C}_{3.8} \mathrm{H}_{5.9} \mathrm{O}_{2.9}$ とした。

燃焼熱, 標準生成熱, 比熱, 蒸気圧といったシステム構成成
分の熱力学デー夕は, 基本的には $\mathrm{PRO} / \mathrm{II}$ のデータ（シムサイ データベース）を用い，多成分系についてはNRTL（Non Random Two Liquid）モデルを用いた。一方，バイオマスに関 連する物質（木材, 灰分, リグニン, セルロース, ヘミセルロー ス, 五炭糖，六炭糖等）のデー夕は十分ではないため, これら のデータについては，実測データを収集し，推算式の形でまと めた。一例を Fig. 2 に示す。

コストデータについては，主要構成機器のコスト，システム 構成成分の価格，プラントコストインデックス（建設工事費, 配管費用, 計装費用の推算方法) 等を文献調查し, さらに外注 分析によるクロスチェックを行った。それぞれの主要構成機器 について, 機器サイズを因子とした価格推算式の形でまとめ た。一例として, Fig. 3 に熱交換器の価格データを示す。

変換プロセスデータについては, トータルシステムを構成す る要素プロセスである成分分離（水熱処理，メカノケミカル処 理), バイオ変換 (酵素糖化, エタノール発酵), 熱化学変換 (ガ ス化，燃焼，発電，触媒合成）のデー夕を，文献および実験を 通じて収集し整理した。

\section{2. 基本ケースの経済性シミュレーション}

基本ケースとして, 国内の最大規模製材所から排出される製 材残材量に相当する $495 \mathrm{t} / \mathrm{d}$ の木材処理量を想定し，プロセス シミュレーションを行った。この規模に相当するプラントの主 要機器のサイズをプロセスシミュレーションにより得られた物 質収支デー夕から求めた。さらに, 価格推算式を用いて主要機 器費を求めると, 総計 88.7 億円となった。計装, 建物, 配管等 で構成される固定費総額（投資総額）は文献㧍よび最近の動向 を考慮した経験則から主要機器費の3 倍として 267 億円となっ た。

運転経費は, 直接運転費 [人件費 $(800$ 万円 $/$ 人 $\cdot$ 年 $\times 12$ 人 $)$, 保守費（固定費の $1 \%$ ），試験および検査費（プラント運転費 の $20 \%$ ) ], 固定資産税（固定費の $1.5 \%$ ）, 保険費（固定費の $0.4 \%)$ ，一般管理費（直接運転費の $25 \%$ ）とした。

年間稼働日数 300 日で製品は完売するという前提において求 めた製品の生産量と売上を Table 1 に示す。

単純投資回収年を次式のように定義し, バイオマス調達費 (原 料費) を変動因子として, 単純投資回収年へのその影響を調べ た（Fig. 4)。

単年度回収費 $=$ 売上高 $-[$ 原料費 + 運転経費 $]$

単純投資回収年 $=$ 投資総額 $/$ 単年度回収費

その結果，原料価格の増加に伴い，単純投資回収年も増加する が，製材残材クラスの 9 千円 $/ \mathrm{t}$ 程度の原料費で投資回収年は 11 年程度となることから，本システムの実現の可能性は低く ないものと考えられる。

\section{3. 開発指針の検討}

基本ケースのプロセスシミュレーション結果をベースとして 各要素技術に対して感度解析を行い，バイオ液体燃料の低コス 卜化の観点から要素技術開発の指針を検討した。はじめに技術 評価（物質収支およびエネルギー収支の改善程度）およびコス 卜評価（固定費, 運転費の改善程度）を行った。また, その技 術評価においてはヒアリング等も行った。その結果をポート フォリオの表としてまとめた（Table 2)。表では，右にあるも のほど経済性の感度が高く ( $\mathrm{E}$ と表現), 技術的にも難易度が 


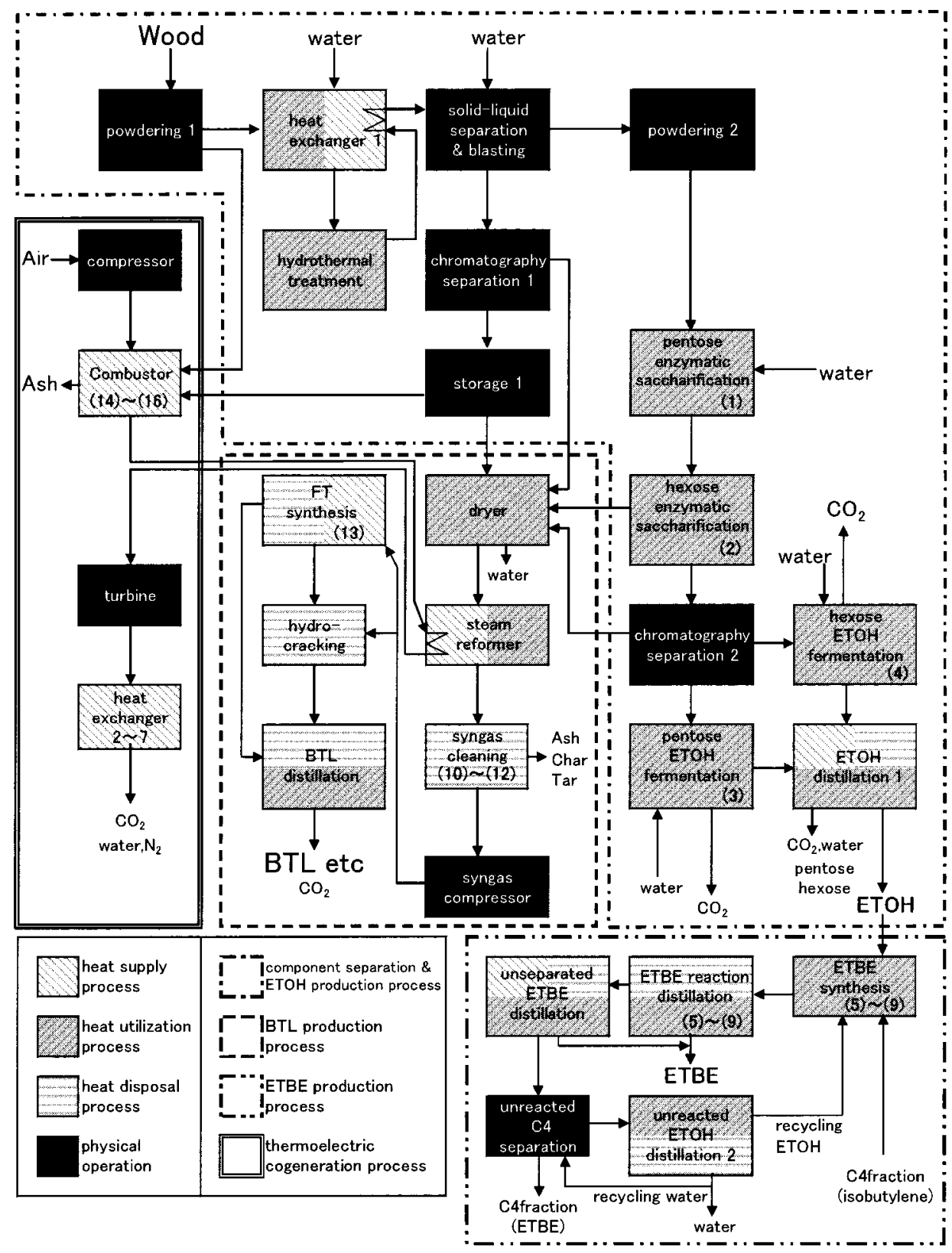

Fig. 1 System Flow of BTL/ETBE Process ${ }^{4)}$

高い (Tと表現)。経済性への感度は, 前処理では粉砕エネルギー と酵素価格が高いことが分かった。粉砕エネルギーに関して は，より高効率な粉砕方法やより低エネルギーでのセルロース の高活性化方法の開発が必要となり，本要素を集中して検討す るべきであることが分かった。酵素に関しては，酵素生産コス 卜を低下させる技術の開発が求められる。

また，エタノール発酵抢よびETBE 製造では五炭糖の発酵と ETBE 製造の経済性の感度が高いことが示された。五炭糖の発 酵性能の向上はそのままエタノール収量の向上につながる。し かしながら, 発酵速度が小さく発酵時間が増加すると, 機器サ イズ，すなわち機器費が向上する。このため五炭糖の高速発酵 が重要となる。また, ETBE 製造も経済性の感度への影響が大 きいものの, 既存の技術を応用できるため研究要素が少ないも

\section{のと思われる。}

BTL では FT 合成用の触媒が経済性に大きく影響する。より 安価な触媒の開発, リサイクルによる再利用の検討等が本シス テムの実用化に向けた研究課題となる。

\section{3. 粉砕技術による酵素糖化前処理}

\section{1. 前処理方法の課題}

木質の主要な構成成分はセルロース，ヘミセルロースおよび リグニンである。バイオエタノールを製造するためには，七ル ロースやへミセルロースをその構成糖に加水分解（糖化）して 発酵する必要がある。加水分解方法として最も一般的なのは酸 加水分解であるが, 酸の回収コストや糖収率, 発酵阻害, 環境 負荷等が課題とされている。一方, 酵素糖化法は低環境負荷で 


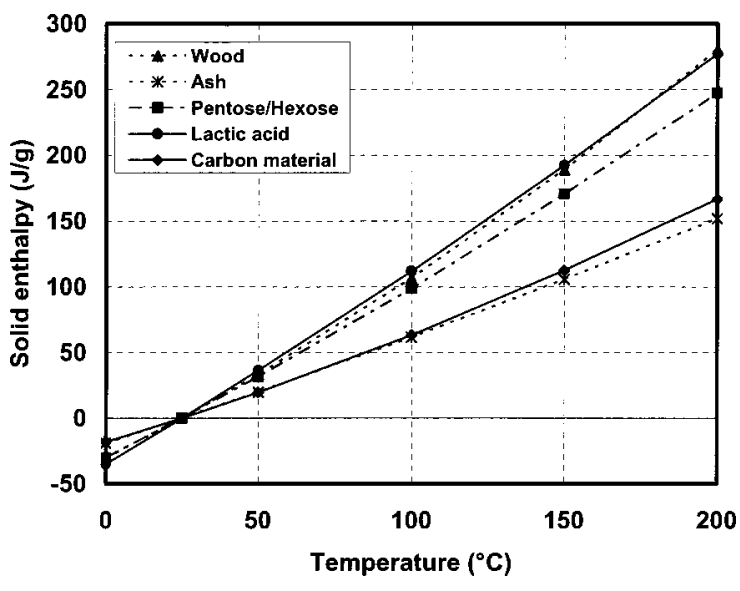

Fig. 2 Enthalpy of the Solid Process Configuration Component ${ }^{4}$

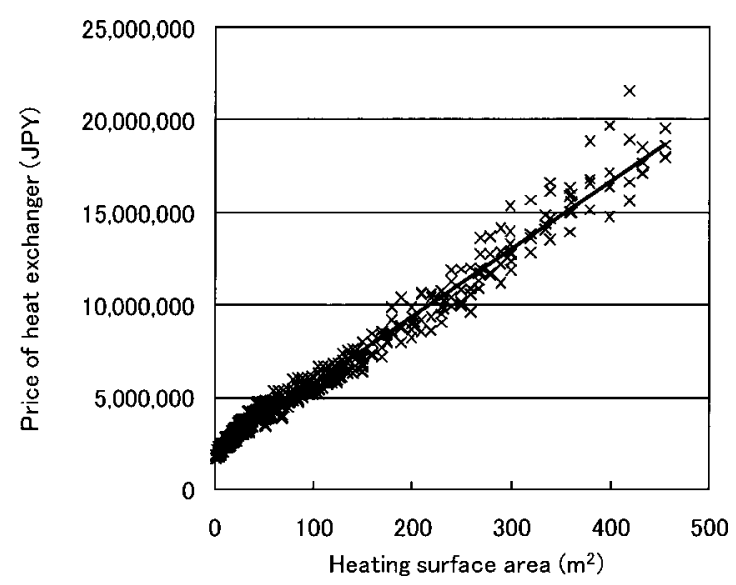

Fig. 3 Relationship between Heating Surface Area and Cost of Heat Exchanger

高収率・高効率が期待される方法であるが，木質の前処理が極 めて重要である。木質においてセルロース成分が最も安定であ るが，その理由はセルロース分子の規則正しい自己集合による 幅数 $\mathrm{nm}$ のセルロースミクロフィブリル（結晶性）の形成と, このミクロフィブリルがさらに層状に積層して強固な木質組織 を形成しているためである。

酵素糖化のための前処理方法としては, 蒸煮処理, 爆砕処理, 粉砕処理などが知られている。蒸煮処理は, 高温・ 高圧の蒸気 処理で, 紙・パルプ分野では化学薬品処理との併用した基盤技 術となっている。爆砕処理は, 高温・高圧蒸気で処理した後, 一気に大気圧に開放して，木質を繊維状にする方法である。蒸 煮や爆砕処理は, 樹種への依存が知られており, すべてのバイ オマスには対応できない場合もある。粉砕処理は, 単純な機械 的処理で樹種依存も低く糖化性は容易に向上させやすいが，多 くの電力を必要としコスト高になる課題がある。

\section{2. メカノケミカル処理と酵素糖化性}

粉砕処理では, 単純に物理的に細かくなる以上に, 分子レベ ルでの変化も起こる。このような粉砕エネルギーによって化学 反応を起こす方法はメカノケミカル処理と呼ばれている。我々 は化学反応として水素結合等の弱い結合の形成や切断までを広
Table 1 Estimated Annual Sales

\begin{tabular}{lccc}
\hline \multirow{2}{*}{ Manufactured goods } & output & unit price & sales \\
\cline { 2 - 4 } & $\mathrm{t} / \mathrm{d}$ & $¥ / \mathrm{kg}$ & million $¥ / \mathrm{yr}$ \\
\hline ETBE & 121.1 & 100 & 3,634 \\
FT diesel & 58 & 80 & 1,391 \\
Combustible gas & 72.1 & 15 & 325 \\
\hline \multicolumn{1}{c}{ Total } & & & 5,350 \\
\hline
\end{tabular}

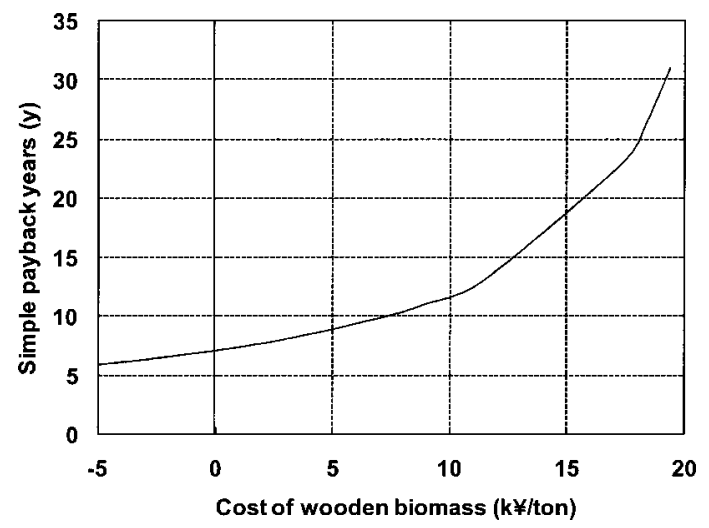

Fig. 4 Simple Payback Year of the Woody Biomass Utilization Process ${ }^{4)}$

く含めてメカノケミカル処理ととらえている5

木材を粉砕すると酵素分解性が向上することは以前より知ら れている6)。条件を適切に選べば $10 \mu \mathrm{m}$ 以下の微粒子も製造が 可能である7)が, 粒径と酵素糖化性が相関しない場合がある。 そこで, 粉砕処理で酵素分解性が向上する機構を明らかにする 目的で, 粉砕処理木粉の特性と酵素糖化性の関連について調べ た。

実験用試料としては製紙用ユーカリチップおよび米松チップ をカッターミルにより $0.2 \mathrm{~mm}$ 程度に粗粉砕した木粉を用いた。 メカノケミカル処理は遊星型ボールミルにより行った。

原料木粉をボールミル粉砕した場合の生成木粉の粒径の変化 を明らかにするために, 生成物を水に分散させ, レーザー回折 式粒度分布計でフローセルを用いて粒度分布を測定した (Fig. 5)。その結果, 粉砕とともに粉砕生成物の粒径は次第に 小さくなっていったが, 粉砕時間が 1 時間以上になると生成粒 子の粒度分布はほぼ同一（平均粒径約 $20 \mu \mathrm{m} ）$ となり, 長時間 粉砕しても微粒子は生成しないことが分かった。これは, 走査 型電子顕微鏡（SEM）観察などから粉砕中に生成した1 次粒子 の再凝集が起こっているためと考えられる。この再凝集力は強 く, 水や緩衝液中で超音波照射しても容易には微粒子に分散で きなかった。

次に, ユーカリからの粉砕生成物を酢酸緩衝液に分散させ, 酵素として市販セルラーゼを加えて $45^{\circ} \mathrm{C}$ で加水分解試験を 行った。セルロース糖化して生成したグルコース量については, 酵素法による比色定量により求めた。糖化試験の結果を Fig. 6 に示す。ユーカリでは粉砕時間が長くなるのに従ってグルコー ス生成量は増加した。粉砕 1 時間以降は粒度分布計では粒径の 変化がほとんどないにもかかわらず, グルコース生成量は増加 
Table 2 Portfolio for Development of Our System

\begin{tabular}{|c|c|c|c|c|c|}
\hline Economic sensitivity (E) & Low & & & & High \\
\hline \multicolumn{6}{|l|}{ Items } \\
\hline Low energy mechanochemical treatment & & & & & $\mathrm{E}, \mathrm{T}$ \\
\hline Low energy hydrothermal process & & & $\mathrm{T}$ & $\mathrm{E}$ & \\
\hline Low cost enzymatic saccharification & & & & & $\mathrm{E}, \mathrm{T}$ \\
\hline Xylose fermentation & & & & $\mathrm{T}$ & $\mathrm{E}$ \\
\hline Glucose fermentation & E, T & & & & \\
\hline Ethanol recovery (distillation) & $\mathrm{T}$ & E & & & \\
\hline ETBE production & $\mathrm{T}$ & & & $\mathrm{E}$ & \\
\hline High yield gasification & $\mathrm{T}$ & $\mathrm{E}$ & & & \\
\hline $\mathrm{H}_{2} / \mathrm{CO}$ ratio & $\mathrm{T}$ & $\mathrm{E}$ & & & \\
\hline Dry cleaning of gas & & & $\mathrm{T}$ & $\mathrm{E}$ & \\
\hline FT catalyst for biomass gasified gas & & & & & $\mathrm{E}, \mathrm{T}$ \\
\hline Technical difficulty $(\mathrm{T})$ & Commercial & Bench & Lab. & Fundamental & Idea \\
\hline
\end{tabular}

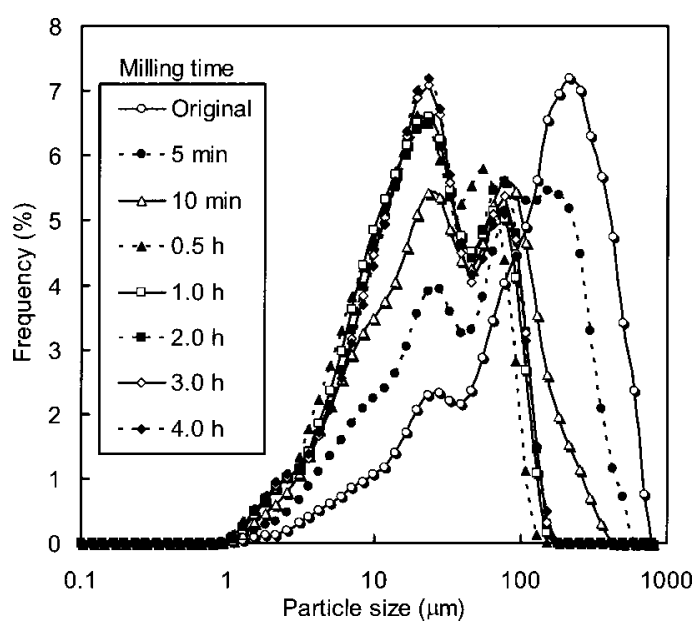

Fig. 5 Particle Distributions of the Milled Products from Eucalyptus

したことから，粒度分布計で測定できる単純なミクロンオー ダーの粒径を評価基準として酵素糖化性を推測することは困難 であることが分かった。

\section{3. メカノケミカル処理による木質の構造変化}

木質中では，セルロース成分のみが結晶性を持っており，他 のへミセルロースやリグニンは非晶質である。従来から木質や パルプを機械的粉砕してセルロースの結晶性を低下させること が酵素糖化性の向上のために重要と言われている。そこで, 粉 砕試料の結晶構造の変化について粉末 X 線回折により調べた。 比較のため，精製木材パルプ（日本製紙ケミカル，KCフロッ ク W-100)についても同様に粉砕処理し, 結晶性㧍よび糖化性 について調べた。Fig. 7 に, 粉砕時間によるセルロースの結晶 化度と 24 時間後の糖化率の関係について示す。ユーカリの場 合, 粉砕によりセルロース成分の結晶性は急激に低下したが, グルコース生成量の増加は緩やかな曲線となった。一方, 精製 木材パルプの場合も, 粉砕に従って結晶化度は急激に低下した

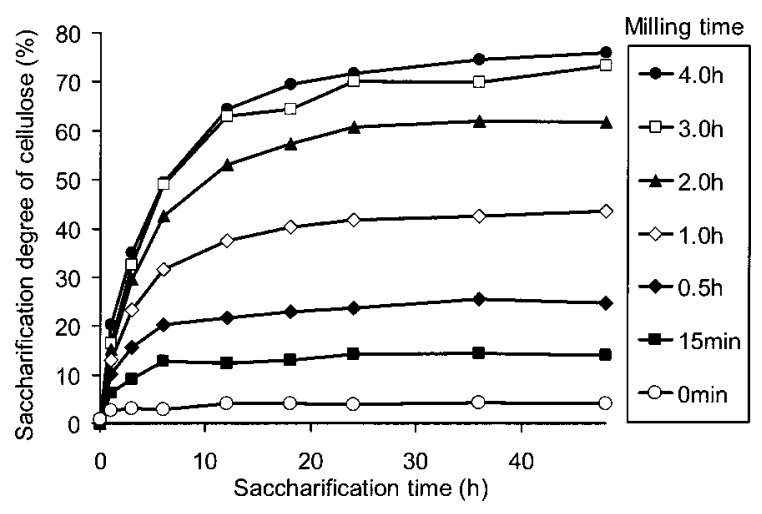

Fig. 6 Effect of Milling Time on the Saccharification of Cellulose

が, 未粉砕試料（結晶化度 $57 \%$ ）でも酵素糖化性は高く, 粉 砕の糖化性への寄与はわずかであった。以上の結果から，木質 バイオマスの酵素糖化では，セルロース成分の結晶性が低いほ ど酵素糖化性は向上すると言えるが, 糖化性と結晶性の相関が 高くなく, 精製木材パルプでは結晶性が高くても酵素糖化が進 行していることから, 結晶性が糖化性を支配する重要因子では ないことが示された。

粉砕では, 強い圧力やせん断力によって, 木質成分の分子構 造が破壞されることも考えられるため, 赤外分光分析および固 体核磁気共鳴（NMR）分析により，分子構造の変化について も調べたが, 酸化などによる基本分子構造の破壊は観測されな かった。また，木質中のリグニンの低分子化や分解の影響につ いて調べるために, $90 \%$ ジオキサン抽出を行った。その結果, ユーカリの 4 時間粉砕後のリグニン抽出率はわずかに $3 \%$ であ り, リグニンの分解や分離はほとんど起こっていないことが分 かった。

次に, 酵素糖化性に影響する重要因子について調べるため, 木質構成成分の分子運動性の評価を行った。固体 NMR では, 分子構造の解析以外に, 緩和時間測定から分子運動性を調べる 


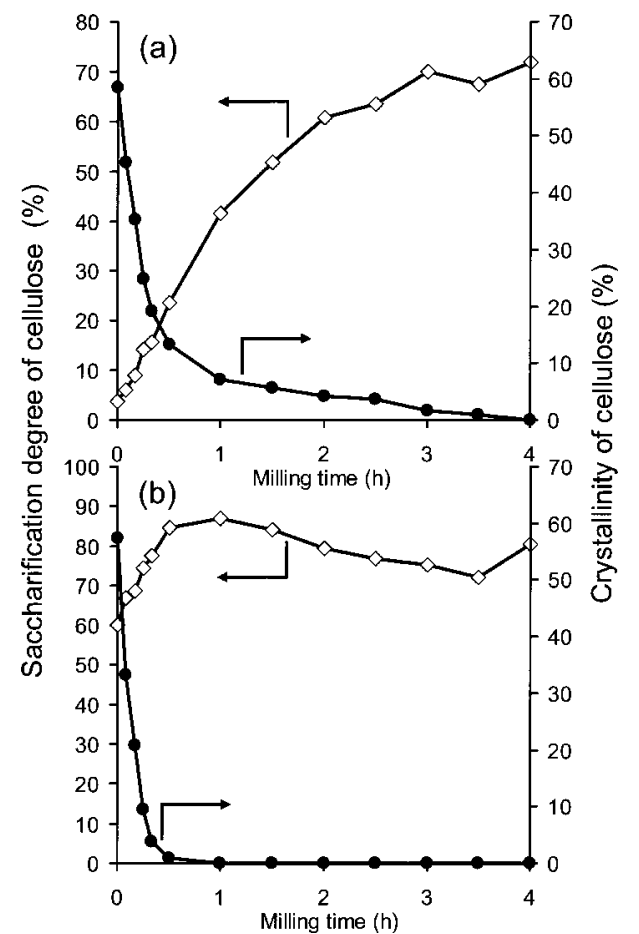

(a) Eucalyptus, (b) purified pulp.

Fig. 7 Relationship between Saccharification Degree and Crystallynity of Cellulose

ことができる。Fig. 8に，固体 NMR により測定した木質構成 成分の緩和時間 $\left(T_{1}^{\mathrm{H}}\right)$ の変化を示す。測定は試料が吸湿して いる状態 (約 $15 \mathrm{wt} \%$ ) で行った。その結果, 粉砕時間が長く なるのに従って緩和時間は減少し, 計算より求められる運動し ている領域の大きさは，4時間後では $5 \mathrm{~nm}$ 程度となり，七ル ロース分子の集合体であるミクロフィブリル程度の単位で分子 運動できる状態にあることが分かった ${ }^{8)}$

以上のことから木質の粉砕により酵素糖化性が向上する要因 として, 木粉の粒径やセルロースの結晶性よりはミクロフィブ リルが解かれて酵素が接近し易くなっていることが重要である ことが示された。

\section{4. 微細繊維化処理}

前項で述べたように，固体 NMR 測定から酵素糖化性を向上 させるためにはミクロフィブリル単位での酵素との相互作用が 重要であることが示された。そこで, 実際に木質をミクロフィ ブリルに解かす方法について検討した。原料木粉を 10 ２0倍 量（重量比）の水に懸濁させて, ボールミルにより湿式メカノ ケミカル処理を行った。得られた褐色のクリーム状生成物の特 性を分析するためには乾燥試料を得る必要があるが，微細繊維 化処理は水系で行っているため, そのまま凍結乾燥等を行うと 凝集が強く起こる。そのため, クリーム状生成物の水をアルコー ルに置換して減圧乾燥を行うことにより, 凝集を抑制して水系 での形態をほぼ保持したまま乾燥することができた。得られた 乾燥生成物については, 結晶性, 形態および糖化性について評 価を行った。

乾燥生成物を SEM 観察したところ, 幅 $100 \mathrm{~nm}$ 以下の微細緎

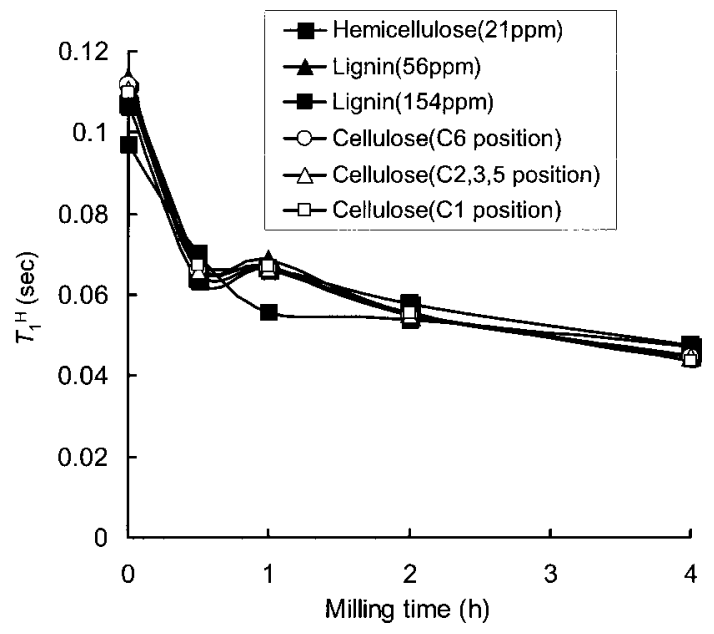

Fig. 8 Effect of the Milling Time on ${ }^{1} \mathrm{H}$ Spin-lattice Relaxation Time $\left(T_{1}^{\mathrm{H}}\right)$

維が生成していることが分かった。次に，X 線回折により結晶 性を調べたところ，原料とほぼ同等であったことから，湿式メ カノケミカル処理ではミクロフィブリル構造があまり破壊され ることなく, 解かされていることが分かった。通常, セルロー スの X 線回折では, ミクロフィブリル1本の幅の領域（3〜 $5 \mathrm{~nm}$ ）しか原理的に測定できないため, 結晶性の低下が見られ ないことは, フィブリル化がスムーズに進行していることを示 している。

次に, 生成物の酵素糖化性について調べた。生成物ではセル ロース成分は高い結晶性を保持しているにもかかわらず，比較 的高い糖化性を示した。ユーカリの場合, 48 時間加水分解後 の糖化率は約 40\%, 米松の場合では約 59\% であった。

微細繊維化方法を効率化する目的で, ディスクミルによる処 理方法について検討した。ディスクミルは高速で回転する電動 石臼（うす）方式で, 連続処理が可能である。原料木粉濃度 $5 \mathrm{wt} \%$ のスラリーをディスクミルにより繰り返し粉砕し, 生成 物の特性および糖化性について調べた。生成物は粉砕回数とと もに粘度が上昇し, 生成物を乾燥後にSEM 観察したところ, ボールミルの場合と同様に微細繊維が生成していた。生成物の 糖化性は処理回数が増えるに従って向上したが, 5 回程度で十 分であることが分かった。実験で用いたデイスクミルは, ディ スク径 $250 \mathrm{~mm}$, 回転数 $1800 \mathrm{rpm}$ で, 処理時間は原料木粉濃度 $5 \mathrm{wt} \%$ のスラリー $10 l$ で, 1 回約 3〜 5 分であった。また, $3 \mathrm{~mm}$ パスの原料木粉からの処理も可能であった。

ディスクミルを用いた湿式メカノケミカル処理では, 短時間 かつ連続処理により, 前処理コストを大幅に削減できる可能性 がある。Fig. 9に前処理のイメージを示す。木質に限らず植物 系バイオマスからのバイオエタノール製造では，セルロース等 の成分分子の性質や構造特性をマクロからナノレベルまで把握 して, 効率的な前処理方法を構築することが重要である。

\section{4. 酵素糖化法の検討 99,10$)$}

従来の希硫酸法は, 七ルロースからの糖収率が低いため, 糖 化酵素を用いて糖化を行う酵素糖化法が注目されている。木質 バイオマスは, リグニン, セルロース, ヘミセルロースから構 


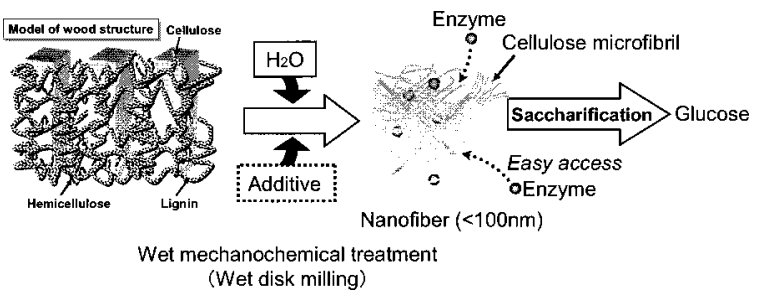

Fig. 9 Proposed Mechanism for the Wet Mechanochemical Treatment of Wood

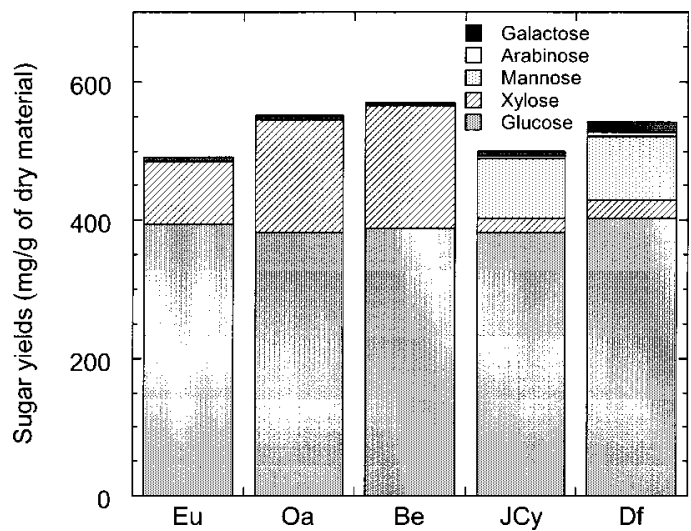

Eu, eucalyptus; Oa, Oak; Be, Beech; Jcy, Japanese cypress; Df, Douglas fir.

Fig. 10 Sugar Composition of Enzymatic Hydrolysate of Mechanochemically Treated Woods ( $2 \mathrm{~h}$-milling) ${ }^{9}$

成されるが，セルラーゼとへミセルラーゼをいきなり作用させ ても，リグニン等の 3 次元ネットワーク構造が邪魔をして, 加 水分解はほとんど起こらない。水熱処理やメカノケミカル処理 された木質バイオマスをアクレモニウムセルラーゼ(明治製菓) で処理するとグルコース等が生成する。ヘミセルラーゼ活性を 補うと，全糖収率がさらに向上することが分かった。

\section{1.メカノケミカル処理-酵素糖化法}

Fig. 10に示すように, 遊星型ボールミルによるメカノケミ カル処理は, 針葉樹・広葉樹とも酵素糖化性を大きく向上させ る。メカノケミカル処理は水熱処理や爆砕に比べ, より多くの 樹種に適用可能であることが分かる。

ユーカリではメカノケミカル処理時間に応じて，処理基質の 酵素糖化におけるグルコース収率とキシロース収率が向上する ことが分かった。したがって, メカノケミカル処理の作用は, セルロースミクロフィブリルの破壊よりも, むしろセルロースヘミセルロースーリグニンの3 次元ネットワーク構造を破壊し ていると考えられる。遊星型ボールミル2 時間処理後, $40 \mathrm{FPU} /$ $\mathrm{g}$-前処理バイオマスの酵素量を添加することによって, グルカ ンの $88 \%$ とキシランの $79 \%$ が加水分解された。私たちは, メ カノケミカル処理したユーカリがさらに少ない酵素添加量で加 水分解できることを見い出している。ユーカリをメカノケミカ ル処理後, $4 \mathrm{FPU} / \mathrm{g}$-前処理バイオマスの酵素処理によってグル カンの $81 \%$ とキシランの $72 \%$ がグルコースとキシロースにそ れぞれ分解された。これらのことは，メカノケミカル処理が酵

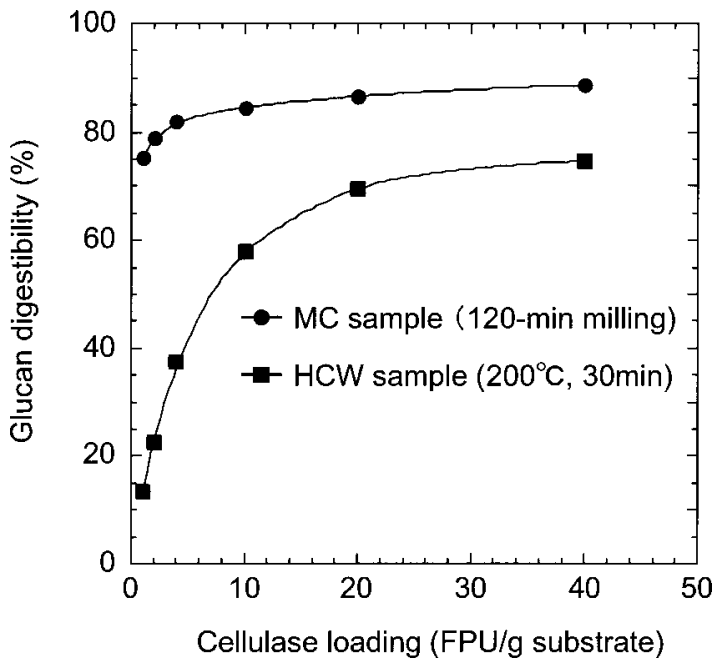

MC: mechanochemical milling; HCW: hot-compressed water treatment $^{10)}$.

Fig. 11 Effect of Cellulase Loading on Glucan Digestibility of Pretreated Eucalyptus

素糖化の前処理として有用であることを示している（Fig. 11）。

\section{2. 水熱処理-酵素糖化法}

ユーカリを水熱処理するとへミセルロースが可溶化し, キシ ロースを含む可溶性キシランとして回収される。最も高い可溶 性キシランの収率は $65 \%$ で, その時の処理温度は $180^{\circ} \mathrm{C}$ であっ た。キシロースは $180^{\circ} \mathrm{C}$ 以上の水熱処理によりフルフラールに 分解されるため, 収率はそれ以上には上がらなかった。原料中 のへミセルロースが可溶化するのに伴い, 水熱処理したユーカ リ残さの酵素処理によるグルコース収率は向上した。グルコー ス収率からの最適処理条件は $200^{\circ} \mathrm{C}, 30$ 分で, $77 \%$ のグルカン が $40 \mathrm{FPU} / \mathrm{g}$-前処理バイオマスの酵素処理でグルコースに加水 分解された。この条件でのキシロース収率はとても低く，21\% であった。セルラーゼの添加量を $4 \mathrm{FPU} / \mathrm{g}$-前処理バイオマスに すると，グルコース収率は $38 \%$ に低下した。水熱処理では, メカノケミカル処理の5倍にあたる20 FPU/g-前処理バイオマ スの酵素量が必要であった（Fig. 11）。

\section{3. 水熱-メカノケミカル処理-酵素糖化法}

2 時間のボールミル処理は酵素糖化性を大きく向上させる が，消費エネルギーも高い。一方，水熱処理は先に報告したよ うに酵素必要量は比較的多いが, 消費エネルギーは低いことが 知られている。メカノケミカル処理の消費エネルギーを低下さ せるために，水熱法との組合せを検討した。Fig. 12 に示すよ うに，水熱処理後メカノケミカル処理することにより，メカノ ケミカル処理の時間を短くすることができた。投入エネルギー およびグルコース収率の観点から水熱一メカノケミカル処理法 の最適条件は水熱 $160^{\circ} \mathrm{C}, 30$ 分, メカノケミカル処理 40 分であ り, 水熱処理のみの場合に比べよりマイルドな水熱条件で処理 すればよいことが分かった。 $200^{\circ} \mathrm{C} ， 30$ 分水熱処理後にメカノ ケミカル処理を 2 時間行うと, 逆に酵素反応に阻害効果が認め られた。水熱処理のみを行う場合と異なり, 水熱処理後ボール ミル処理したリグニンにはセルラーゼ活性を阻害する働きがあ 
ることが推定される。 $160^{\circ} \mathrm{C}, 30$ 分水熱処理後, メカノケミカ 儿処理 40 分行った残さを $4 \mathrm{FPU} / \mathrm{g}$-前処理バイオマスの酵素量 で糖化すると，未処理原料の $77 \%$ のグルカンがグルコース (372 mg/g 原料) に, $54 \%$ のキシランがキシロース $(68 \mathrm{mg} / \mathrm{g}$ 原料）に変換された。さらに，水熱処理によって可溶化したキ シランを加算するとキシロースの回収は理論上 $84 \%(99.5 \mathrm{mg} / \mathrm{g}$ 原料）に達した。これらの収率は, メカノケミカル処理のみ 40分行ったユーカリの酵素糖化に扔けるグルコース抄よびキ シロース回収率に比較して, それぞれ 1.2 倍および 1.7 倍高いも のであった。

\section{4. まとめ}

メカノケミカル処理により，樹種によらず大きく醖素糖化性 が向上することが分かった。2時間ボールミル処理したユーカ リは，4 FPU/g-前処理バイオマスという少ない酵素量で糖化す ることができた。一方, $200^{\circ} \mathrm{C}, 30$ 分の水熱処理は, $20 \mathrm{FPU} / \mathrm{g}$ 前処理バイオマスというメカノケミカル処理に比べより多くの 酵素を必要とした。水熱処理とメカノケミカル処理を組み合わ せることにより，メカノケミカル処理時間を短縮できることが 明らかとなり，前処理の省エネルギー化の可能性が示された。

\section{5. 非硫酸バイオエタノール製造プロセスの構築}

2章で述べたように，非硫酸前処理によるバイオエタノール の製造には粉砕動力の低減と酵素糖化工程価格の低減が必須で ある。本章では，3，4章での検討を基に非硫酸バイオエタノー ル製造プロセスを提案する。

\section{1. 低動力粉砕（湿式ディスクミル）}

3章で述べたように，粉砕による酵素糖化率向上の本質はセ

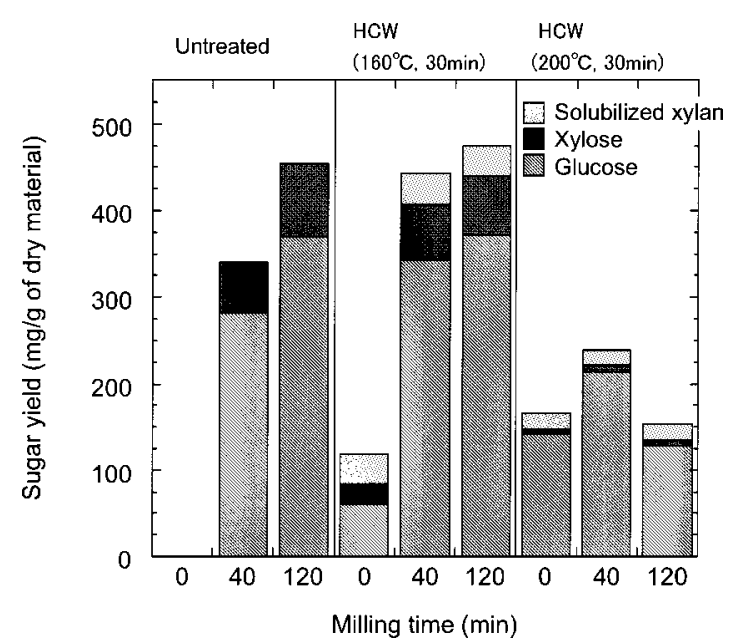

Fig. 12 Enzymatic Digestibility (4 FPU/g of substrate) of the Eucalyptus Treated by a Combination of Hot-compressed Water and Mechanochemical Milling ${ }^{9)}$
ルロースのミクロフィブリルと酵素との相互作用の容易さであ り，「解纎」が重要である。これをいかに低動力で実現できる かという観点から，ボールミルを用いた場合とディスクミルを 用いた場合の必要動力をラボ規模で比較した（Table 3 $)^{11)}$ 。粉 砕では粉砕動力の原単位は規模の-0.2 乗となるといわれてお $り^{12)}$,この結果から実規模（100 t/d）での必要動力を推算した。 ディスクミルではボールミルの場合と比較してかなり低動力に なることが分かった。

しかしながら，これでも木材の有するエネルギー（高位発熱 量で約 $20 \mathrm{MJ} / \mathrm{kg}$ wood (dry)) の $5 \%$ 以上を占める。さらなる 低動力化のため水熱処理との組合せも検討した。4章で述べた ように, 水熱処理とメカノケミカル処理を組み合わせることで 粉砕時間が約 1/3に短縮できることが分かった（Fig. 12）。一 方, 水熱処理を組み合わせると加熱エネルギーが追加で必要に なる。水熱処理での加熱エネルギーは回収も可能であるので, それも考慮して必要エネルギーを推算した。その結果, 水熱処 理+湿式ディスクミルによる必要エネルギーは合計で $3.2 \mathrm{MJ} /$ kg wood（dry）と推算され, より一層の必要エネルギーの低減 が可能である。

\section{2. 酵素オンサイト生産の経済性}

酵素糖化工程のコストは, 酵素調達コストと酵素使用量の積 となる。酵素調達コストの低減の一方策としてオンサイト生産 を検討した。実験室規模での酵素生産実験の結果を基に, 酵素 オンサイト生産のプロセス設計と経済性評価を行った。プロセ 又設計に扔ける物質収支の結果を Fig. 13に示す ${ }^{13)}$ 。この結果か ら酵素調達コストを推算すると $100 \mathrm{t} / \mathrm{d}$ 規模で約 300 円 $/ \mathrm{kg}$ 酵 素となった。現状の試薬レベル $(10,000$ 円 $/ \mathrm{kg}$ 酵素 $)$ ～大量 購入レベル $(1,000$ 円 $/ \mathrm{kg}$ 酵素 $)$ よりも安価に製造できること が分かった。これは販売のための精製が不要であることや，原 料の購入費用を見積もらなくてよいこと, 輸送費用が不要なこ となどのためと考えられる。もちろん, 酵素の販売価格がオン サイト生産よりも安価になれば購入する方が経済的に有利にな

\begin{tabular}{|c|c|c|c|c|c|}
\hline Input & & & Output & & \\
\hline water & $1.019 \mathrm{~m}^{3}$ & & top layer & 0.917 & $\mathrm{~m}^{3}$ \\
\hline glucose & $72.078 \mathrm{~kg}$ & & (protein & 14.113 & $\mathrm{~kg})$ \\
\hline$\left(\mathrm{NH}_{4}\right)_{2} \mathrm{SO}_{4}$ & $8.939 \mathrm{~kg}$ & & (other & 8.546 & $\mathrm{~kg})$ \\
\hline $\mathrm{NH}_{3}$ gas & $0.975 \mathrm{~kg}$ & & & & \\
\hline & & curtivation & residue & 0.102 & $\mathrm{~m}^{3}$ \\
\hline air & $230.649 \mathrm{~m}^{3}$ & & (solution & 0.102 & $\left.m^{3}\right)$ \\
\hline & & & (protein & 1.568 & $\mathrm{~kg}$ ) \\
\hline & & & (fungi & 13.246 & $\mathrm{~kg})$ \\
\hline & & & (other & 0.950 & $\mathrm{~kg}$ ) \\
\hline
\end{tabular}

Fig. 13 Estimated Material Balance at the Enzyme Production Process (unit, per $1 \mathrm{k} l$ ethanol) ${ }^{13}$ )

Table 3 Required Energy at Milling Process

\begin{tabular}{lccc}
\hline \multicolumn{1}{c}{ Mill type } & Ball mill & Disk mill \\
\hline Scale at lab. test & & $100 \mathrm{~g}, 2 \mathrm{~h}$ & $500 \mathrm{~g}, 0.5 \mathrm{~h}$ \\
Required energy & {$[\mathrm{kWh} / \mathrm{kg}$ wood (wet) $]$} & 30 & 4 \\
Estimated required energy at large scale & {$[\mathrm{MJ} / \mathrm{kg}$ wood (dry) $]$} & 31 & 4.1 \\
\hline
\end{tabular}




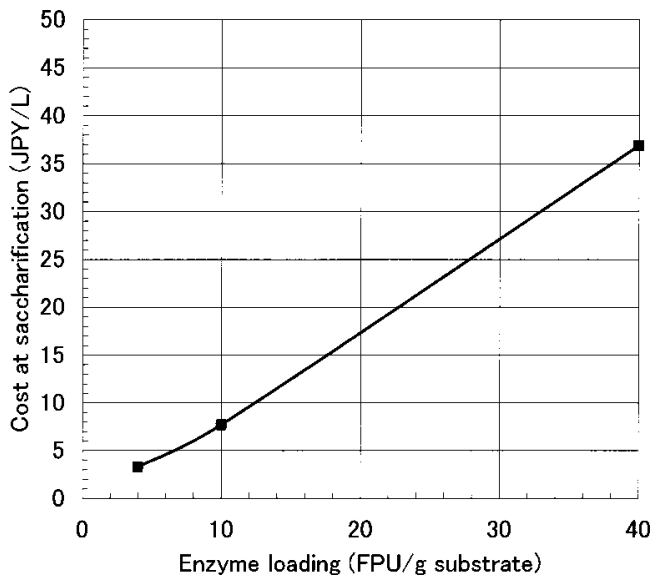

Assumption: Scale, 100 t/d of wood; Operating days, 300 days/year; Payback time, 9 years.

Fig. 14 Relationship between Enzyme Loading and Saccharification Process Cost

る。

一方, 酵素オンサイト生産の場合, 原料の一部を酵素生産の ために使用することとなり，酵素使用量も重要な因子となる。 Fig. 14 に酵素使用量と酵素糖化工程コストの関係を示す ${ }^{11}$ 。 外部から購入する場合は原点を通る直線となる一方, オンサイ 卜生産の場合は酵素使用量が増加すると酵素生産のために使わ れる原料が増える分コストは上昇することになる。4章で前処 理法による酵素使用量と糖化率の関係を示したように

(Fig. 11), メカノケミカル処理（微粉砕）の場合, 酵素使用 量を低減できることが期待される。高温での水熱処理は酸を 使った化学処理と本質的に同じであり，硫酸やアンモニアを 使った前処理では酵素使用量を下げられないことが知られてい る。酵素使用量の観点からもメカノケミカル処理（微粉砕）の 優位性が言える。

\section{3. 非硫酸バイオエタノール製造プロセスの提案}

以上の検討を基に非硫酸バイオエタノール製造プロセスを消 費エネルギーの観点から検討した。Fig. 15にケース 1 として湿 式微粉砕を採用した場合の全体プロセスの必要エネルギーを, ケース 2 として水熱処理 + 湿式微粉砕を採用した場合の必要工 ネルギーを示す。罒に示すように粗蒸留工程での必要エネル ギーが大きくなることが分かる。これは, 湿式処理のため固形 物濃度が低く, 糖化・発酵後のエ夕ノール濃度が低いことが原 因である。そこで脱水工程を入れたプロセスを検討したところ (ケース 3$)$, 脱水工程に必要なエネルギーは小さいこと, 粗蒸 留工程での必要エネルギーが大きく低減されることが分かっ た。低温での水熱処理や機械的処理では可溶化が起きないかわ ずかであることから，脱水工程を追加してもロスはほとんどな く，これも機械的処理のメリットの一つである。

これらの検討を踏まえ，非硫酸バイオエタノール製造プロセ スのフロー図を Fig. 16のように提案する。すなわち, 粗粉砕, 水熱処理, 湿式微粉砕, 脱水, 一部を利用しての酵素オンサイ 卜生産，酵素糖化，エタノール発酵，粗蒸留，無水化精製の各 工程からなるプロセスである。今後はこのプロセスの実用化を

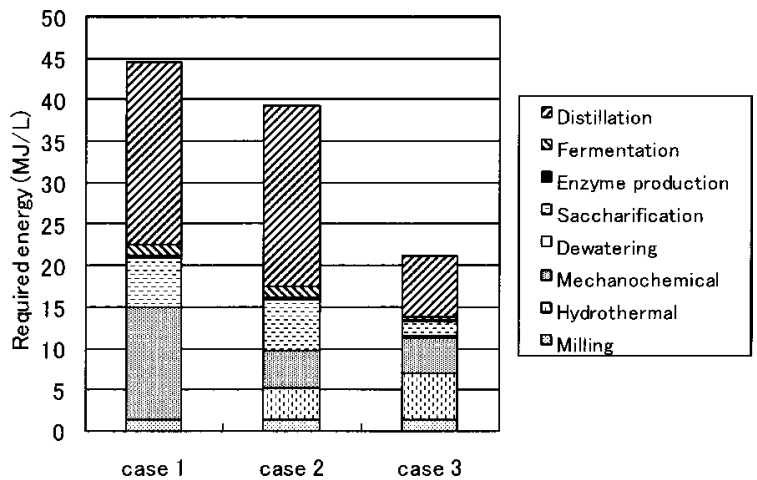

case 1, Mechanochemical pretreatment. case 2, combination of hydrothermal and mechanochemical pretreatment. case 3, with dewatering after pretreatment.

Fig. 15 Required Energy for Total Process of Ethanol Production

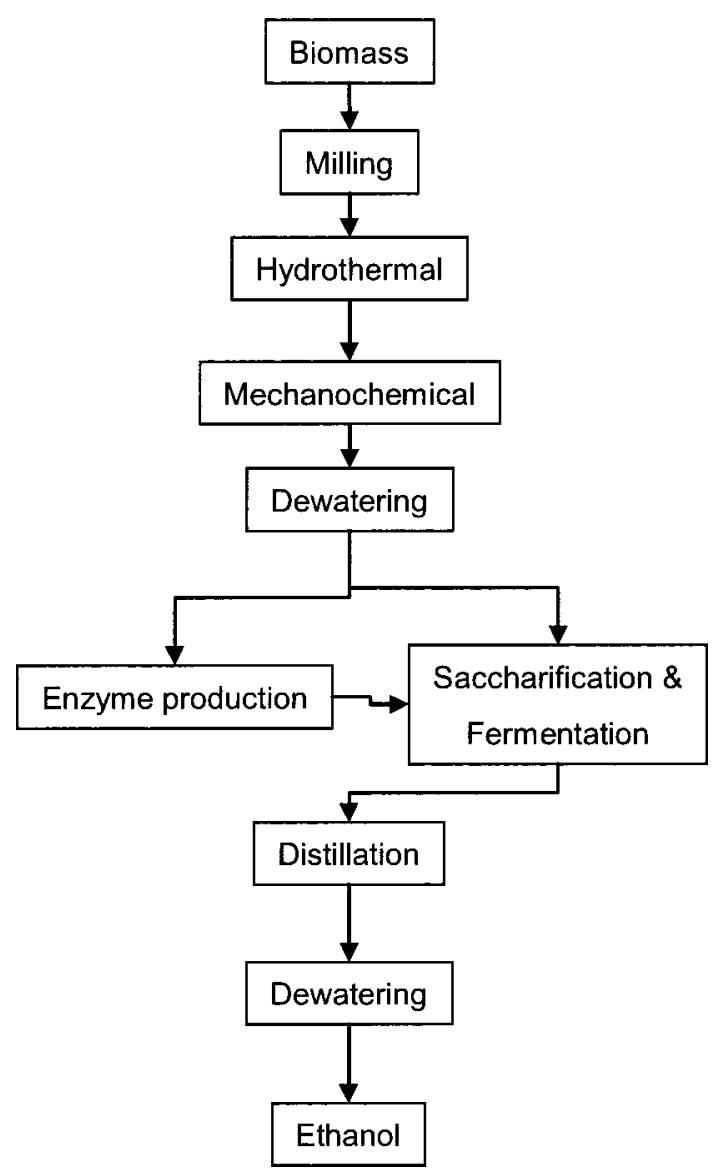

Fig. 16 Process Flow for Ethanol Production from Biomass with Combination of Mechanochemical Pretreatment and Enzymatic Saccharification

目指し，まずはベンチスケール規模で実証を行いたい。

\section{6. おわりに}

京都議定書の第一約束期間の発効を来年（2008年）に控え， 国内外でより一層の炭酸ガスの排出削減が求められており, 
カーボンニュートラルで再生可能なバイオマス由来の液体燃料 を製造し，石油，石炭，天然ガス等の化石資源を代替する技術 開発の実用化が喫緊の課題となっている。バイオマス資源は, 未利用の木質系を中心に草本系の天然バイオマスや，農産廃棄 物系, 古紙, 生ごみ, 污泥等の廃棄物系バイオマスに大別され, 各地域で分散して存在するため, その効率の良い収集・運搬シ ステムの構築が非常に重要となってくる。特に，食料と競合し ないリグノセルロース系バイオマス資源を効率良く収集・前処 理して，エタノールや BDF，ジメチルエーテル（DME）等の 輸送用燃料に変換するトータルシステムおよびその評価システ ム技術の開発は, 山間部を含む地域分散型のエネルギー供給シ ステムを，“適原料・適地”で実証し，経済性・環境性に優れ たバイオ燃料製造プロセスの実用化を目指す上で，必要不可欠 であると言える。

バイオ燃料の製造コストは従来の石油系燃料に比べれば割高 と言わざるを得ないが，バイオ燃料は炭酸ガス削減効果のみな らず，硫黄，窒素等のへテロ化合物や芳香族が含まれていない ことから, 自動車排ガス浄化の観点からも有利である。また, 昨今の 1 バレルが 100 ドルにも迫る原油高騰のあおりを受けて (2007年 12 月現在)，ガソリンや灯・軽油等の石油製品価格が 急騰しており, バイオ燃料導入への期待も高まっている。農産 廃棄物や製材残材等のリグノセルロース系バイオマス資源から のバイオエタノール製造技術は，硫酸法を中心に実証プラント 開発が進められているが，今回紹介したような環境・調和型の 非硫酸法による低エネルギー型の前処理技術は，基本的には水 だけを使用するため種々のバイオマス資源や混合原料にも対応 できる可能性を有している。さらに, 酵素糖化法との組合せ最 適化, セルラーゼ等の酵素のオンサイト生産, あるいはグルコー
ス・キシロースの同時発酵技術の開発等により, 市販ガソリン 価格と競合できるバイオエタノールの生産が可能になると期待 される。

\section{References}

1) Yano, S., Proceeding of Fourth Biomass-Asia Workshop, (2007).

2) Sawayama, S., Yano, S., Sakanishi, K., J. Soc. Automotive Engineers Jpn., 61, (11), 16 (2007)

3) Fukuda, T., Kuroda, M., Fujimoto, S., Sasaki, Y., Sakanishi, K. Minowa, T., Yabe, A., Energy \& Resources, 27, (4), 282 (2006).

4) Fujimoto, S., Minowa, T., Sakanishi, K., Catalysts \& Catalysis, 49, (4), 254 (2007)

5) Endo, T., Chou, P., Shinohara, Y., Cellu. Commun., 9, (2), 86 (2002).

6) Tanaka, R., Yaku, F., Murai, E., Koshijima, T., Cell. Chem. Technol., 14, 859 (1980).

7) Endo, T., Ago, M., Cellu. Commun., 11, (2), 74 (2004).

8) Endo, T., Material Stage, 6, (11), 56 (2007).

9) Inoue, H., Yano, S., Endo, T., Sakaki, T., Sawayama, S., Proceedings of Renewable Energy 2006, 1124 (2007).

10) Yano, S., Inoue, H., Endo, T., Sakaki, T., Sawayama, S., 2nd Baiomasukagakukaigi Happyouronbunshu, 24 (2007).

11) Fujimoto, S., Minowa, T., Inoue, H., Sawayama, S., Endo, T., 16th Nippon Enerugi Gakkai Taikai Kouenyoushishu, 198 (2007).

12) The Society of Powder Technology, Japan, "Handbook of Powder Technology,” Nikkankogo Shinbunsha, Tokyo (1986), p. 494.

粉体工学会編, “粉体工学便覧, ” 日刊工業新聞社, 東京 (1986), p. 494.

13) National Institute of Advanced Industrial Science and Technology, 18FY Report of Entrusted Research, (in press).

要旨

リグノセルロース系バイオマスからの非硫酸バイオエタノール製造法の開発 一メカノケミカル前処理・酵素糖化法一

藤本 真司, 井上 宏之, 矢野 伸一, 坂木 剛, 美濃輪 智朗,

遠藤 貴士，澤山 茂樹，坂西 欣也

(独) 産業技術総合研究所 バイオマス研究センター, 737-0197 広島県点市広末広2-2-2

昨今, バイオエタノールへの関心が高まっている。現在のバ イオエタノールは糖やデンプンを原料にしていることから食料 との競合が懸念されており, リグノセルロース系バイオマスか らのバイオエタノール生産の実用化が喫緊の課題である。リグ ノセルロース系バイオマスからのバイオエタノール製造では硫 酸を使う方法が一般的ではあるが，より環境に優しい方法とし
て, 我々は硫酸を使わない方法の開発に取り組んできた。具体 的には微粉砕と酵素糖化を組み合わせた糖化方法である。プロ セス工学の観点から課題を抽出して, 低エネルギーでの微粉砕 処理, 低コストでの糖化処理を研究開発した。これらの技術を 組み合わせてプロセスを構築することで，プロセスの実用化に 目処がついた。 